\title{
MUNDIALIZAÇÃO DA AGRICULTURA E O USO DE AGROTÓXICOS NO MUNICÍPIO DE GUARANÉSIA - MG
}

\section{MUNDIALIZATION OF AGRICULTURE AND THE USE OF AGROTOXICS IN THE CITY OF GUARANÉSIA - MG}

\author{
Renata Vieira de Melo \\ Universidade Federal de Alfenas, Mestranda no Programa de Pós-Graduação em Geografia MG, Brasil \\ renata.vieirademelo78@gmail.com \\ Flamarion Dutra Alves \\ Universidade Federal de Alfenas, Professor no Programa de Pós-Graduação em Geografia MG, Brasil \\ dutrasm@yahoo.com.br
}

\section{Resumo}

A utilização maciça de agrotóxicos impacta também a economia, apropriando o lucro agrícola dos pequenos agricultores, uma vez, que parte do capital é destinada a compra desse tipo de insumos. percebe-se que nosso espaço agrícola é um retrato da subordinação da agricultura brasileira ao capital internacional já que a implantação da Revolução Verde ocorreu por meio da imposição das indústrias de agrotóxicos com a presença marcante do incentivo realizado pelo governo brasileiro cujos insumos são comercializados, principalmente, por empresas transnacionais. Nesta perspectiva levando em consideração o uso crescente de agrotóxicos, os casos de contaminação dos rios, a submissão dos agricultores ao uso destes produtos, a pressão exercida pelas cooperativas e pelo sul de Minas Gerais ser uma região grande produtora de café no país (conhecida pela ampla utilização de agrotóxicos) essa reflexão se justifica por buscar compreender a mundialização da agricultura e a territorialização do uso de agrotóxicos e consequentemente os impactos socioeconômicos para a agricultura familiar, e assim, poder elucidar a realidade agrária no município de Guaranésia-MG como também no cenário nacional.

Palavras-chave: Agricultura Familiar. Sul de Minas Gerais. Agrotóxicos. Cafeicultura. Agronegócio.

\begin{abstract}
The massive use of agrotoxic also impacts the economy, appropriating the agricultural profit of small farmers, since part of the capital is destined to the purchase of this type of inputs., it can be seen that our agricultural space is a portrait of the subordination of Brazilian agriculture to international capital since the implementation of the Green Revolution occurred through the imposition of agrotoxic industries with the strong presence of the incentive made by the Brazilian government whose inputs are traded,
\end{abstract}


mainly by transnational corporations. In this perspective taking into account the increasing use of pesticides, cases of river contamination, the submission of farmers to the use of these products, the pressure exerted by cooperatives and the south of Minas Gerais to be a large coffee producing region in the country (known for widespread use of pesticides) this reflection is justified by seeking to understand the globalization of agriculture and the territorialization of the use of agrotoxic and consequently the socioeconomic impacts on family farming, thus being able to elucidate the agrarian reality in the municipality of Guaranésia-MG as well as in national scene.

Keywords: Family farming. South of Minas Gerais. Agrotoxic. Coffee growing. Agribusiness.

\section{Introdução}

É evidente que no mundo todo houve um aumento expressivo no consumo de agrotóxicos, nesse contexto nosso país lidera desde 2008 o ranking de consumo mundial dessas substâncias sendo responsável por consumir $1 / 5$ de toda comercialização (CARNEIRO et. al., 2015). O Brasil é um país fortemente dependente do mercado mundial de produtos agroquímicos, e a atual realidade é o reflexo das condições históricas que incentivam a utilização de agrotóxicos a partir da modernização agrícola. O lucro e acumulação de capital tornaram-se objetivos centrais em detrimento as preocupações com a saúde humana e bem-estar ambiental.

As sucessivas transformações no campo ocorreram a partir da chamada "Revolução Verde", os efeitos da modernização a partir da década de 1960 somados a adoção de políticas neoliberais alcançaram o campo brasileiro alterando significativamente os modelos produtivos, ocorreu à inserção de novas práticas agrícolas, a utilização de maquinários nos sistemas produtivos, a utilização de agrotóxicos, justificados na ampliação da produtividade do campo e proteção das plantas contra a ação das pragas.

Os agrotóxicos muitas vezes intitulados “defensivos agrícolas” se ampliaram sobre a argumentação de que estes garantiriam a produção de alimentos em larga escala para combater a fome e a proteção das plantações contra a ação de pragas, no entanto, analisando a lógica de mercado das grandes empresas ligadas ao ramo agroindustrial o intuito da utilização estava voltado à maximização da produção para a obtenção do lucro.

A comunidade científica, ao observar o aumento do uso de agrotóxicos, ampliou paralelamente os estudos científicos acerca dos impactos sociais, ambientais e 
econômicos que essa utilização desenfreada acarreta e possa acarretar. Estudos recentes do SISAGUA/Ministério da Saúde (2019) apontam para contaminação da água dos rios que abastecem centros urbanos por agrotóxicos em centenas de cidades brasileiras, casos de morte, intoxicação e tentativas de suicídio ligado a essas substâncias também apresentam um crescimento anual vertiginoso (CARNEIRO et al., 2015).

Nesta realidade seja via alimentos ou pela água, é praticamente inevitável que resíduos de agrotóxicos da produção agrícola cheguem à mesa do brasileiro, colocando em risco a vida de milhares de pessoas que estão sendo intoxicadas diariamente por meio da atividade que deveria ser mais respeitada- a alimentação.

A utilização maciça de agrotóxicos impacta também a economia, apropriando o lucro agrícola dos pequenos agricultores, uma vez, que parte do capital é destinada a compra desse tipo de insumos. De acordo com o Censo Agropecuário/IBGE (2017) as propriedades que têm entre 10 a 100 hectares, a porcentagem daquelas que utilizaram agrotóxicos no ano do Censo alcançou 38,18\%. Estes dados são extremamente reveladores de um intenso processo de subordinação da renda da terra ao capital industrial monopolista.

As políticas públicas influenciaram significativamente o uso dos agrotóxicos na produção de alimentos no Brasil. O Programa Nacional de Defensivos Agrícolas, lançado em 1975, impulsionou o uso de agrotóxicos na agricultura, tornando os produtores dependentes das empresas multinacionais, severamente onerosas para $o$ nosso país (PELAEZ, TERRA e SILVA, 2010). Sendo assim o papel desempenhado pelo Estado foi fundamental para incrementar a produção brasileira dos agrotóxicos, somado à normatização favorecendo a disseminação dos mesmos no espaço rural.

Percebe-se que nosso espaço agrícola é um retrato da subordinação da agricultura brasileira ao capital internacional, já que a implantação da Revolução Verde ocorreu por meio da imposição das indústrias de agrotóxicos com a presença marcante do incentivo realizado pelo governo brasileiro cujos insumos são comercializados, principalmente, por empresas transnacionais.

As aquisições facilitadas por incentivos creditícios, aproximaram o setor industrial e financeiro ao setor agrícola e, ao mesmo tempo, o campo e a cidade tornaram-se dependentes do uso de agrotóxicos. O que acaba por maquiar o custo real e 
por subsidiar economicamente e ideologicamente a decisão do agricultor em aderir ao modelo agroquímico de produção.

A territorialização das empresas produtoras de agrotóxico se realiza no espaço agrário brasileiro através da internacionalização da agricultura, tais empresas encontram no espaço agrário brasileiro um espaço potencial para a reprodução do seu capital monopolista o que evidencia a subordinação da renda da terra ao capital internacional, sendo a apropriação da renda da terra efetivada através da compra da dependência de insumos e consequentemente ao endividamento do agricultor.

Nesta perspectiva levando em consideração o uso crescente de agrotóxicos, os casos de contaminação dos rios, a submissão dos agricultores ao uso destes produtos, a pressão exercida pelas cooperativas do e pelo sul de Minas Gerais ser uma região grande produtora de café no país (conhecida pela ampla utilização de agrotóxicos) essa reflexão se justifica por buscar compreender a territorialização do uso de agrotóxicos e consequentemente os impactos socioeconômicos para a agricultura familiar.

Diante do exposto o objetivo geral do artigo é analisar como ocorre a mundialização da agricultura e o uso de agrotóxicos na agricultura familiar no município de Guaranésia-MG, pois acreditamos que o município represente um recorte espacial da realidade sul mineira, e a partir desta análise, como objetivo específico constatar se realmente apresenta uma viabilidade socioeconômica a utilização de agrotóxicos pelos agricultores familiares num comparativo com a produção orgânica. $\mathrm{E}$ ainda como objetivo específico, analisar a produção de café no município e no contexto regional e o uso de agrotóxicos.

Efetivamente cabe destacar que a agricultura não é tema exclusivo do campo, dizendo respeito a toda sociedade brasileira, assim como, o uso de agrotóxicos está deixando de ser uma questão relacionada especificamente à produção agrícola e se transforma em um problema de saúde pública. O impacto pelo uso abusivo e indiscriminado destes produtos é imensurável afetando diretamente as atuais e futuras gerações, assim como é difícil dimensionar os danos ambientais a eles associados.

\section{Procedimentos metodológicos}

Para compreender a realidade agrária em que está inserido o município de Guaranésia, realizou-se revisões bibliográficas abordando a temática da mundialização da 
agricultura, assim como, para obter informações referentes ao uso de agrotóxicos, produções agrícolas, setores da economia, consultou-se diversos órgãos, entidades, institutos de pesquisas e banco de dados em busca de informações relevantes e dos dados secundários necessários. Foram feitas consultadas em dados estatísticos do Instituto Brasileiro de Geografia e Estatística (IBGE / Produção Agrícola Municipal - PAM) / Sistema de Recuperação de Dados do IBGE - SIDRA e dados dos Censos Agropecuários); Empresa de Assistência Técnica e Extensão Rural do Estado de Minas Gerais (EMATER), Secretaria Municipal de Meio Ambiente e Agropecuária da Prefeitura Municipal de Guaranésia, Cooperativa Regional de Cafeicultores em Guaxupé (COOXUPÉ), o Atlas: Geografia do Uso de Agrotóxicos no Brasil e Conexões com a União Europeia (BOMBARDI, 2017) e também dados junto ao SINAN - Ministério da Saúde e SINITOX - Fiocruz/Ministério da saúde, respectivamente: Sistema Nacional de Agravo de Notificação e Sistema Nacional de Informações Tóxico - farmacológicas onde buscamos notificações das intoxicações por agrotóxicos de uso agrícola.

Deu-se ênfase nos dados secundários ao uso de agrotóxicos e da produção de café no município e no contexto regional, da Região Geográfica Imediata de Guaxupé e sua inserção no sul de Minas Gerais. Assim, a proposta é entender o local e suas relações e interações regional e globalmente.

Para embasamento empírico visando o levantamento de dados primários, abordou-se como procedimento metodológico a realização de trabalhos de campo nas feiras livres. Esses dados foram colhidos por meio de entrevistas com os feirantes agricultores familiares, que foram selecionadas aleatoriamente, e que responderam acerca dos modos de produção, incentivos governamentais, utilização de agrotóxicos, mão de obra utilizada, utilização de crédito entre outros aspectos.

A partir do trabalho de campo realizamos registros fotográficos e mapeamos o município de estudo.

\section{Da modernização à mundialização da agricultura}

A Revolução Verde, nome dado às transformações advindas da modernização da agricultura e em todo um processo econômico-político iniciado na década de 1960, desencadeou o uso intensivo de agrotóxicos e fertilizantes sintéticos na agricultura, hoje a utilização de tais substâncias danosas à saúde, assim como, ao meio ambiente é um 
fato corrente no campo e está presente na vida de muitos produtores em diversas áreas do mundo; todavia, para se chegar ao atual estágio, foi exigida toda uma gama de fatores que marcaram a sociedade no instante de seu surgimento. Para tanto, faz-se necessário compreender o contexto vivenciado, e, a partir disso, desvendar os reais objetivos do processo de modernização da agricultura. Nesse sentido, vai ser possível perceber as reais intenções da grande empresa na modernização da agricultura: a maximização do lucro, através da monopolização de fatias cada vez maiores do mercado; e a aquisição de maquinário especializado, por intermédio dos pacotes tecnológicos. Assim criaria um círculo de dependência para o agricultor que só conseguiria os pacotes tecnológicos produzidos pelas transnacionais a partir de incentivos creditícios concedidos pelo Estado, caso contrário, a não inserção nesse novo modelo de produção acarretaria na perda de vendas de seus produtos ao mercado externo como uma das consequências diretas.

Uma das proposições para tais alterações no campo era o aumento da produtividade agrícola que advinha, em grande parte, pela instrumentação de novas tecnologias de produção, em especial pelo encadeamento de agentes químicos utilizados tanto para o controle e o combate a pragas quanto para o estímulo do crescimento de plantas e frutos.

Nesse contexto, buscou-se no presente trabalho, analisar algumas questões sobre o processo de mundialização da agricultura, como também, da territorialização da agricultura moderna no Brasil, procurando destacar o papel do Estado e do capital privado na consolidação desse processo e consequentemente os novos usos do território.

Segundo Brum (1988), as principais razões da modernização da agricultura são:

a-) elevação da produtividade do trabalho visando o aumento do lucro;

b-) redução dos custos unitários de produção para vencer a concorrência;

c-) necessidade de superar os conflitos entre capital e o latifúndio, visto que a modernização levantou a questão da renda da terra;

d-) possibilitar a implantação do complexo agroindustrial no país.

No concernente ao sistema econômico da sociedade hodierna, referente à mundialização da agricultura, que é o objeto empírico deste estudo, Oliveira (2002) esclarece que ocorrem duas formas de reprodução do capital no campo, sendo elas, a territorialização e a monopolização do capital. A primeira se refere a um mecanismo 
especificamente capitalista, em que o capitalista se torna também proprietário de terra. Dessa forma, ocorre uma apropriação (pelo capitalista/proprietário) simultânea do lucro da atividade industrial e da agrícola, como também da renda da terra. A monopolização do território é uma maneira que o capital monopolista encontrou para se reproduzir através de formas não capitalistas de produção, redefinindo as relações de produção, na qual o próprio capital cria as condições para o campo produzir as matérias-primas para as indústrias capitalistas.

Sendo assim, a mundialização atua na agricultura através dos processos de territorialização dos monopólios e monopolização dos territórios. O primeiro atua simultaneamente, no controle da propriedade privada da terra, do processo produtivo no campo e do processamento industrial da produção agropecuária $\mathrm{O}$ segundo é desenvolvido pelas empresas de comercialização e de processamento industrial, que sem produzir no campo, podem controlar fazendeiros capitalistas e camponeses através de mecanismos de subordinação.

Para Graziano da Silva (1996), o termo modernização da agricultura é utilizado para designar a transformação na base técnica da produção agropecuária no pós-guerra, as modificações intensas da produção no campo e das relações capital x trabalho. Esse período é marcado pela dependência do mercado externo dos meios de produção. Assim, a consolidação efetiva da agricultura moderna culminou na adoção das inovações tecnológicas no processo produtivo (inovações agronômicas, físico-químicas, biológicas) como também, na construção dos complexos agroindustriais (CAIs), o que acarretou uma nova configuração socioeconômica e espacial para o espaço agrário brasileiro.

Graziano da Silva (1996) nos apresenta as fases da modernização da agricultura no Brasil. A primeira se restringe à transformação da base técnica, induzida e estimulada pelo governo e empresas norte-americanas. A segunda fase caracteriza-se pela industrialização da produção rural com a implantação de indústrias de bens de produção e de alimentos. Na terceira fase, ocorre plena integração entre a agricultura e a indústria. E por último, ocorre a integração de capitais (industriais, bancários, agrários) sob o comando do capital financeiro.

Destacando o poder fundamental do Estado na normatização, regulação e condução de estratégias de modernização para o campo, Graziano da Silva (1998) atesta que a modernização da agricultura patrocinada pelo Estado foi conservadora e dolorosa. 
Conservadora porque beneficiou produtores e áreas e dolorosa devido às contradições sociais geradas pela expansão do capital.

A agricultura sob o viés capitalista voltada a acumulação massiva de lucro se pautou sobre três pilares para efetivar a reprodução do capital, são esses: a produção de commodities, as bolsas de mercadorias e de futuro e a formação de empresas monopolistas mundiais. A atuação da agricultura neoliberal ocorre através do controle da propriedade privada da terra, do processo produtivo e industrial do campo (territorialização dos monopólios) e por meio das empresas que processam e vendem alimentos sem produzir nada no campo, subordinando os fazendeiros e camponeses à sua lógica de mercado (monopolização dos territórios) (OLIVEIRA, 2002).

Ainda nessa perspectiva, o capital vai transformando as relações trabalhistas e produtivas na agricultura:

$\mathrm{Na}$ agricultura, esse processo de subordinação das relações não capitalistas de produção se dá, sobretudo, pela sujeição da renda da terra ao capital. O capital redefiniu a renda da terra pré-capitalista existente na agricultura; ele agora se apropria dela, transformando-a em renda capitalizada da terra. É nesse contexto que devemos entender a produção camponesa: a renda camponesa é apropriada pelo capital monopolista, convertendo-se em capital. (OLIVEIRA, 1986, p. 67).

A respeito da convergência da agricultura com a indústria temos a formações de Complexos Agroindustriais, no entanto é fundamental esclarecer que tais complexos agroindustriais se fundamentaram sob os moldes da modernização conservadora e da revolução que, diga-se, foi uma revolução bem pouco verde (ABRAMOVAY, 2012), trouxeram consigo um pacote tecnológico que envolvia a mecanização do campo, uso intensivo de fertilizantes, e para complementar o pacote tecnológico, os agrotóxicos, chamados eufemisticamente de "defensivos agrícolas".

As últimas décadas do século XX sinalizaram a expansão das agroindústrias e consumos de agrotóxicos no país, coadunando com essas circunstâncias nosso intuito é evidenciar a conjuntura da utilização de agrotóxicos no Brasil sob os efeitos da mundialização da agricultura.

As alterações nos modos de produção, por consequência ou em razão da mundialização do capital, e da agricultura tem na indústria de agrotóxicos um de seus principais expoentes e foram através de ações como os incentivos fiscais, crédito rural, normas flexíveis, falta de controle, que o mercado de agrotóxicos foi fortemente subsidiado pelo Estado e pode se expandir na agricultura brasileira. Com destaque o 
sistema de crédito que obteve fundamental importância, já que o crédito rural é a principal alavanca da industrialização no campo, um dos instrumentos de consecução do planejamento governamental para a agricultura (MÜLLER, 1989, p.63).

Conforme Delgado (1985), Kageyama et al. (1990), Graziano da Silva (1998) e Mazzali (2000), o Estado brasileiro patrocinou e incrementou variadas políticas direcionadas ao campo voltadas para viabilizar o processo de modernização da agricultura brasileira acerca dessas políticas destacamos: fornecimento de crédito subsidiado para custeio, investimento e comercialização de produtores rurais e agroindústrias (Sistema Nacional de Crédito Rural - SNCR); garantia de preço mínimo e seguro de safra aos produtores rurais e comerciantes; estímulos fiscais e econômicos à instalação de empresas transnacionais do ramo agrícola (bens de capital e de produção) e agroindustrial; criação e articulação de empresas públicas de pesquisa agropecuária (como a Empresa Brasileira de Pesquisa Agropecuária - EMBRAPA, criada em 1973) com grandes empresas; oferta de assistência técnica e incentivo à extensão rural (como a Empresa Brasileira de Assistência Técnica e Extensão Rural, EMBRATER, criada em 1974 e extinta em 1990); criação de uma rede de armazéns públicos; investimentos em sistemas de transportes (rodovias, ferrovias, portos); de energia (produção e transmissão) e promoção da ocupação e colonização de fronteiras agrícolas.

A junção entre a agricultura e a indústria se intensificou, principalmente a partir da década de 1970, sendo a dependência entre os setores uma marca desse período. As agroindústrias cresceram como processadoras de produtos provenientes da agropecuária e se modernizaram, tornando-se mais exigentes.

De acordo com Elias (2003, p.321),

Podemos identificar uma terceira fase da reestruturação produtiva da agropecuária brasileira em meados da década de 1970. Nesse período, dá-se um processo de integração de capitais a partir da centralização de capitais industriais, bancários, agrários, etc., expansão de sociedade anônima, cooperativas agrícolas, empresas integradas verticalmente (agroindústrias ou agrocomerciais), assim como a organização de conglomerados empresariais por meio de fusões, organização de holdings, cartéis e trustes, com atuação direta nos CAIs.

Ainda, corroborando com esta afirmativa sobre as interações da agricultura com a indústria, Mazzali (2000), define Complexos Agroindustriais (CAIs) como estruturas capitalistas que retratam a articulação da agricultura, por um lado, com a indústria 
produtora de insumos e bens de capital agrícolas e, por outro lado, com a indústria processadora de produtos agrícolas, a agroindústria (MAZZALI, 2000, p. 17).

Assim, quando há a transição do modo tradicional de produzir para o moderno, ocorre a formação do complexo agroindustrial, marcado pela simbiose entre a indústria e agricultura, havendo subordinação total do trabalho agrícola ao capital industrial e financeiro (MÜLLER, 1989, p. 47).

A atribuição das variadas dimensões das atividades desenvolvidas pelos CAIs é destacada por Müller (1989, p.45).

O complexo agroindustrial, CAI, pode ser definido, em termos formais, como um conjunto formado pela sucessão de atividades vinculadas à produção e transformação de produtos agropecuários e florestais. Atividades tais como: a geração destes produtos, seu beneficiamento/transformação e a produção de bens de capital e de insumos industriais para as atividades agrícolas; ainda: a coleta, a armazenagem, o transporte, a distribuição dos produtos industriais e agrícolas; e ainda mais: o financiamento, a pesquisa e a tecnologia e a assistência técnica.

Para Mazzali (2000), a indução do setor financeiro beneficiou estruturalmente a economia agrícola, pois:

O crédito farto com taxas de juros altamente subsidiadas visou favorecer o setor agropecuário em seu conjunto, tendo como clientela preferencial o produtor (modernizado ou modernizável), privilegiando, por meio das diferentes modalidades (investimento, comercialização e custeio), a indústria de bens de capital produtora de veículos, máquinas e implementos agrícolas, além de equipamentos de beneficiamento e de armazenagem. Também foram beneficiadas as cooperativas agrícolas, a indústria processadora e as indústrias química e petroquímica, produtoras de fertilizantes e defensivos agrícolas (MAZZALI, 2000, p. 23).

Sobre essa nova dinâmica na agricultura, Graziano da Silva (1998) pontua:

Agora a dinâmica da agricultura estará determinada pelo padrão de acumulação industrial, centrado no desenvolvimento dos complexos agroindustriais, e a ação do Estado nesse contexto orienta-se para a modernização da agricultura, visando integrá-la ao novo circuito produtivo liderado pela indústria de insumos e processamento de matéria-prima e gerando as condições infraestruturais necessárias à expansão do conjunto do setor (GRAZIANO DA SILVA, 1998, p. 23).

A partir das reflexões realizadas neste item podemos atribuir ao aumento do consumo dos agrotóxicos no Brasil ações que foram historicamente conduzidas pelo Estado, ações essas que acarretaram em converter o Brasil numa região de interesse para as empresas líderes em produção de veneno despontar no cenário mundial. É importante salientar que tais políticas, além de incentivar o uso massivo de venenos, não apresentavam paralelamente a correspondente proteção legislativa contra os efeitos 
futuros gerados pelas substâncias nocivas empregadas no campo de modo intensivo e indiscriminado. É fundamental destacar também que na legislação brasileira não há previsão de revisão de registro de agrotóxicos, sendo muitos liberados há muitos anos e jamais revistos a fins de correção (CARNEIRO et al. 2015). Além do mais, a estrutura dos órgãos regulares se mostra demasiadamente insuficientes. Pra completar essa realidade catastrófica a mudança ocorrida nos rótulos em que há a extinção do pictograma "caveira" das embalagens, em produtos "Não Classificados" (ANVISA, 2019), permite a ocultação dos riscos, uma vez que, parte da população que está em contato com esses venenos não possuem escolaridade em graus elevados e as figuras representativas do perigo e, até mesmo, morte facilitam a identificação de sustâncias perigosas e fazendo com que se redobrem a atenção e o cuidado em seu manuseio.

Pelaez (2010) aponta ações Estatais, verificáveis como: a) a formação do complexo agroindustrial com a modificação da base de produção (modernização conservadora); b) o Plano Nacional de Defensivos Agrícola com a substituição da política de importação de venenos agrícolas. Ambas diretrizes políticas converteram o Brasil numa região de interesse para as empresas líderes em produção de veneno, despontando no cenário mundial. Acrescenta-se, ainda, a criação do Sistema Nacional de Crédito Rural e uma regulamentação defasada e pouco rigorosa, baseada nas normas de defesa sanitária vegetal de 1.934 as quais, além de incentivar o uso massivo de venenos, não apresentava a correspondente proteção legislativa contra os efeitos futuros gerados pelas substâncias empregadas no campo.

O uso de fertilizantes artificiais e agrotóxicos se acentuou a partir da década de 1960, com índices bastante elevados. Segundo Graziano Neto (1985), entre 1965 e 1975 o consumo de fertilizantes cresceu a taxa média de $60 \%$ ao ano, enquanto que os agrotóxicos cresceram numa média anual de $25 \%$.

De acordo com Oliveira (2012) com as políticas neoliberais da década de 90 e a privatização da Petrofértil, em 1994, setor de fertilizantes ficou controlado pelo oligopólio privado das três tradings companies multinacionais: a norueguesa Hydro/Yara, a holandesa Bunge/Fosfertil e norte-americana Cargill/Mosaic. Juntas dominam $90 \%$ do fornecimento de adubos e fertilizantes, ficando o grupo capixaba Heringer como a última empresa nacional no setor. 
A relação da mundialização na agricultura e uso de agrotóxicos é ressaltada por Oliveira (2016):

No setor de agrotóxicos, do Brasil, há o domínio do mercado pela Bayer e Basf (alemãs), Cofco (chinesa/suíça ex-Syngenta), DuPont e Dow Chemical que acertaram fusão e criando gigante de US\$ 130 bilhões, criando três negócios nas áreas de agricultura, commodities e produtos químicos, e a Monsanto (norte-americanas) e ChemChina (chinesa/israelense), que, juntas, formam oligopólios privados de multinacionais estrangeiras na economia nacional. O consumo mundial de agrotóxicos é de cerca de 2,5 milhões de toneladas e, o Brasil responde por mais de 300 mil toneladas. (OLIVEIRA, 2016, p.744-475).

A mundialização assumiu, portanto, as características básicas do capitalismo monopolista no final do século XX, integrando o capital na escala mundial, criando as empresas mundiais.

Segundo Oliveira (2016) A monopolização do território é desenvolvida pelas empresas de comercialização e/ou processamento industrial da produção agropecuária, que sem produzir no campo, controlam através de mecanismos de subordinação, camponeses e capitalistas produtores do campo. Relativo ao assunto, Oliveira (2016, p. 7) ressalta:

Que dois processos monopolistas comandavam e comandam a produção agrícola mundial. De um lado está a territorialização dos monopólios e a monopolização do território. Estas empresas monopolistas do setor de grãos, atuam como players no mercado futuro das bolsas de mercadorias do mundo, e, muitas vezes têm também, o controle igualmente monopolista da produção dos agrotóxicos e dos fertilizantes.

Bombardi (2012) aponta que são seis grandes empresas estrangeiras - Monsanto, Syngenta/Astra Zeneca/Novartis, Bayer, Dupont, Basf e Dow - que controlam mais de $70 \%$ do mercado de agrotóxicos no Brasil.

Os mecanismos utilizados pelo governo para a expansão da agricultura moderna possibilitaram a territorialização de grandes empresas agropecuárias. Estas, por sua vez, causaram grandes alterações espaciais, econômicas, políticas, culturais e ambientais à medida que foram implantados novos sistemas de uso e manejo da terra, baseados na ciência, na tecnologia e na informação, e também novas culturas. "[...] Estado como um agente ativo na globalização da agricultura" (SANTOS; SILVEIRA, 2001, p. 118).

O Decreto $\mathrm{n}^{\circ} 24.114$ de 12 de abril de 1934, ainda vigente, foi o único estatuto normativo que compunha o conjunto de medidas para regular o uso e consumo de agrotóxicos no país até o ano de 1989, quando ocorreu a promulgação da lei atualmente 
vigente: 7.802/89, no entanto, tal decreto possui lacunas o que nos permite conferir flexibilidade e permissividade ao texto.

Portanto, a mundialização da agricultura contribuiu para que o Brasil se tornasse o maior consumidor de agrotóxicos do mundo e a insustentabilidade da agricultura capitalista por sua vez, tornou nossa agricultura dependente do setor monopolista agroquímico onde o produtor depende da semente transgênica ou híbrida, que por sua vez depende de agrotóxicos ou fertilizantes para ser cultivada destinando parte da sua renda para as empresas multinacionais deste setor. E nesse processo de dependência são as grandes empresas mundiais que cada vez mais ditam as regras da produção agrícola mundial.

Diferente da modernização agrícola das décadas de 1960 a 1980, hoje a rede de produção agroindustrial está interligada com os setores de transporte e logística, sendo os fluxos da rede no território. Há, portanto, uma especialização no interior das redes que acaba por intensificar as relações de interdependência entre as empresas e demais agentes econômicos. De acordo com Guilhon (1992), existem redes de dois tipos: as horizontais e as verticais. Nessa perspectiva, pesquisaremos sobre as verticais, pois estas: "envolvem a articulação estreitas das atividades de um conjunto de fornecedores e distribuidores por uma empresa coordenadora que exerce considerável influência sobre as ações desses agentes, além de assegurar o controle estratégico de toda a cadeia" (MAZZALI, 2000, p.158).

Nesse contexto, o processo de territorialização do capital no espaço agrário, que gera a modernização da agricultura, altera não apenas o processo produtivo, como também, altera as formas de apropriação, construção e uso do território. Os usos são estabelecidos e planejados para ocorrer, cada vez mais, a ampliação dos lucros e, portanto, da expansão do capital.

\section{O uso de agrotóxicos no contexto da mundialização da agricultura}

Os agrotóxicos, também conhecidos como agroquímicos são segundo o art. $1^{\circ}$ do Decreto $n^{\circ}$ 4.074/2002: Art. 1 o Para os efeitos deste Decreto, entende-se por:

IV - agrotóxicos e afins - produtos e agentes de processos físicos, químicos ou biológicos, destinados ao uso nos setores de produção, no armazenamento e beneficiamento de produtos agrícolas, nas pastagens, na proteção de florestas, nativas ou plantadas, e de outros ecossistemas e de ambientes urbanos, hídricos e industriais, cuja finalidade seja alterar a composição da flora ou da fauna, a fim de preservá-las da ação danosa de seres vivos 
considerados nocivos, bem como as substâncias e produtos empregados como desfolhantes, dessecantes, estimuladores e inibidores de crescimento (...).

O termo "agrotóxico" começou a ser designada para substituir o termo "defensivo agrícola" após grandes reivindicações da sociedade para evidenciar o verdadeiro significado do produto e os danos e riscos que este pode causar à população e ao meio ambiente (SIQUEIRA; KRUSE, 2008).

Os agrotóxicos são produtos manipulados quimicamente que alteram a composição da flora e da fauna com o objetivo de evitar que doenças, insetos ou plantas daninhas prejudiquem as plantações. $\mathrm{O}$ consumo de agrotóxicos relaciona-se diretamente com a adoção do modelo de agricultura intitulado 'agronegócio', que é uma relação comercial e industrial. O agrotóxico, dentro do agronegócio, correspondente a um veneno sintetizado para combater pragas agrícolas. Entretanto, o uso do agrotóxico também se tornou uma prática comum na agricultura familiar, sobretudo, na produção de commodities, como é o caso da cafeicultura.

Já é de conhecimento público que o Brasil lidera o ranking de consumo de agrotóxicos desde última década, no entanto, mesmo com a acelerada utilização deste tipo de substância as aprovações de novos tipos de agrotóxicos se mostram constante. Em 2018 foi criado o Projeto de Lei (PL) 6299/2018, ainda não votado no Congresso Nacional, conhecido como "Pacote do Veneno", que libera o registro de uma série de agrotóxicos, inclusive aqueles com substâncias que potencializam câncer, má formações genéticas e desregulações endócrinas, os efeitos causados pelo uso desses produtos são ainda mais desastrosos não apenas para a saúde pública como também para o meio ambiente. O projeto de lei, além de liberar diversos tipos de agrotóxicos, retira da Agencia Nacional de Vigilância Sanitária (ANVISA) e do Instituto Brasileiro do Meio Ambiente e dos Recursos Naturais Renováveis (IBAMA) o poder de veto sobre o registro, retirando, portanto, os pareceres ambientais e de saúde pública da análise dos pesticidas.

Diante dessa realidade em setembro de 2019 o Ministério da Agricultura divulgou a liberação de mais 63 tipos de agrotóxicos, com esse registo o país totaliza 325 tipos liberados entre janeiro e setembro deste ano, demostrando que o ritmo de liberação desse produto perigoso à saúde pública segue sendo o mais alto da série histórica. 
Segundo a ANVISA $47 \%$ desses produtos foram classificados como "extremamente" ou "altamente" tóxicos. Além disso, foram classificados pelo IBAMA como "altamente" ou "muito" perigosos ao ambiente (SNA, 2019).

A problemática causada pelo uso abusivo de veneno no campo vem afetando a saúde de milhares de pessoas por ano, sendo seus vestígios encontrados não só nos alimentos como também na água das cidades, de acordo com o Ministério da Saúde a água que abastece uma em cada quatro cidades brasileiras está contaminada por um "coquetel tóxico" de 27 pesticidas combinados. No estado de Minas Gerais os dados totalizam 83 cidades mineiras que apresentaram agrotóxicos na análise da água. Os dados fazem parte do Sistema de Informação de Vigilância da Qualidade da Água para Consumo Humano (SISAGUA), que reúne testes realizados pelas empresas de abastecimento. Dos 27 tipos de pesticidas testados pelas empresas, 16 são classificados como altamente tóxicos pela ANVISA e 11 associados a doenças como câncer, disfunções hormonais, doenças crônicas e má formação congênita (AGÊNCIA PÚBLICA, REPÓRTER BRASIL e PUBLIC EYE, 2019). A presente situação, ao que tudo indica é ainda mais grave, já que nem todos os estados brasileiros realizaram testes nas redes de abastecimento, o que aponta que o número de municípios contaminados pode ser ainda maior.

Entre os agrotóxicos encontrados nas análises de água o que se faz mais presente é o glifosato, agrotóxico mais vendido no Brasil popularmente conhecido como "mata mato" e classificado como provável cancerígeno pela Agência Internacional de Pesquisa em Câncer (IARC), assim como este, outros agrotóxicos encontrados estão associados a disfunções hormonais e reprodutivas (ZHANG et al., 2019). Com isso, as consequências para a saúde não são exclusividade dos trabalhadores rurais, sendo delegada também a população dos centros urbanos que consomem alimentos vindos do campo e utilizam água da rede de abastecimento urbano.

O trabalho de Bombardi (2011) mostra que uso intensivo de agrotóxicos tem sido responsável por milhares de mortes na última década (1900 casos de morte por intoxicação por agrotóxicos no período de 1999 a 2009) e dezenas de milhares de intoxicações no mesmo período (62 mil intoxicações notificadas, segundo o SINITOX).

Isto significa que tivemos por volta de 5.600 intoxicações por ano no país, o que equivale a uma média de 15,5 intoxicações diárias, ou uma a cada 90 minutos. Além 
disso, os casos crônicos, ou seja, de doenças crônicas advindas da exposição constante aos agrotóxicos, dificilmente são notificadas, tais como as alterações no sistema endócrino, efeitos no sistema nervoso central e o desenvolvimento de tumores e cânceres. (BOMBARDI, 2011).

A problemática se faz ainda maior, uma vez que, esses dados advêm de Centros de Controle de Intoxicações sendo o número de centros [Centros de Informação e Assistência Toxicológica - CIATS] insuficiente para cobrir toda a extensão territorial do país e inexistentes em várias regiões produtoras importantes ou de difícil acesso para muitas populações rurais. Além disso, é possível afirmar que muitos trabalhadores rurais não procuram unidades de atendimento médico mesmo ao sentir sintomas advindos da exposição aos agrotóxicos, e em relação às redes hospitalares, a notificação dos casos de intoxicação por trabalhadores rurais é espontânea e voluntária, ficando os registos negligenciados e mesmo assim os registros são altos e apresentam crescimento anual, entre 2007 a 2015 foram notificados 84.206 casos de intoxicação no Brasil (MINISTÉRIO DA SAÚDE, 2018) - em unidades de saúde pública e privada, no entanto, devido a essa instabilidade aos registros concluímos que os impactos a saúde devem ser ainda maiores.

De acordo o IBGE desde 2007, observou-se um acentuado crescimento da taxa de consumo de agrotóxicos em Minas Gerais, enquanto houve um pequeno aumento da área plantada. De maneira geral, esse comportamento é semelhante ao perfil nacional, sendo uma de suas explicações o aumento da produtividade agrícola (capacidade de produzir mais por área cultivada).

O Censo Agropecuário do IBGE, em 2017, recenseou 605.304 estabelecimentos agropecuários em Minas Gerais, sendo que a agricultura familiar predomina em 72,7\% desses estabelecimentos. Dentre os estabelecimentos recenseados para a agricultura familiar, responsáveis por 32\% do Valor Bruto de Produção do estado, está em maior número aqueles responsáveis pela produção de café, milho em grão e feijão.

Observa-se a fragilidade da agricultura familiar em relação ao uso de agrotóxicos. A exposição a essas substâncias tende a ser mais significativa nesse grupo devido à falta de técnicas de manejo adequadas e baixo uso de Equipamentos de Proteção Individual (EPI), entre outros. É evidente que em um país com condições climáticas que favorecem altas temperaturas, os EPIs devem ser repensados, uma vez 
que, em sua maioria é representada por vestimentas pesadas o que eleva a temperatura corporal quando exposto ao sol causando mal-estar no trabalhador rural. No entanto, acreditamos que o uso de EPIs deveria ser a última instância de ferramentas a serem utilizadas já que, em primeira instância o empregador deveria aplicar à medida que elimina o risco, em segunda instância aplicar uma medida coletiva para proteção e em terceira instância, caso não seja suficiente medidas tomadas anteriormente, propor o uso de EPIs, no entanto, percebemos que na política o interesse econômico acaba sobrepondo aos efeitos ambientais e sociais, e o uso de EPIs ao invés de ser reelaborado para conforto térmico é utilizado como justificativa para culpabilizar trabalhadores frente às intoxicações, onde grande parte coloca sobre a responsabilidade do trabalhador fazer uso de tais equipamentos, mas não levam em consideração as dificuldades relativas a esse uso.

É de fundamental importância ressaltar que a produção convencional, que faz uso de agrotóxicos, compromete parte da renda do produtor, podendo levar ao endividamento do mesmo, além da dependência contínua que este tipo de substância acarreta, com isso podemos evidenciar que os impactos causados pelo uso de agrotóxicos não estão relacionados somente com a saúde e com o meio ambiente, mas também afetando diretamente a economia agrícola e ao pequeno produtor, uma vez que a agricultura familiar é responsável por 70\% dos alimentos consumidos no país e 1/3 das pequenas propriedades no Brasil utilizam venenos (BRASIL, 2017).

De acordo com Oliveira (2016) o Brasil é um país fortemente dependente do mercado mundial de fertilizantes, pois, para suprir as necessidades do mercado nacional, em 2010, foi necessário importar 62,3\% do volume consumido.

Dentre as culturas que mais fazem uso deste tipo de substâncias temos que soja, milho, algodão, cana e café consomem o total de $76 \%$, sendo que somente soja, milho e algodão levam 55\%. Consequentemente este consumo está concentrado territorialmente nas regiões Centro-Sul que ficou com $86 \%$ (Centro-Oeste 30\%, Sudeste 29\%, Sul $28 \%$ ) e o Norte/Nordeste com apenas $14 \%$. A partir desses dados podemos inferir que o antigo discurso de que o uso de agrotóxicos proporcionaria o aumento da produtividade e consequentemente fim da fome no mundo é um discurso falacioso, uma vez que, grande parte da cadeia de agrotóxicos é utilizada na produção de commodities que não são classificadas como produtos alimentícios essenciais. 
O Estado de Minas Gerais concentra 12\% do total de uso de agrotóxico do país, o café- principal produto agrícola do estado concentra 7\% deste uso (BOMBARDI, 2011, BOMBARDI, 2012).

Nos estudos de Alves (2019a, 2019b) foi observada a relação entre a presença de agrotóxicos no agronegócio do café com as principais regiões produtoras, as maiores microrregiões produtoras de café Varginha, São Sebastião do Paraíso e Alfenas, são justamente as que mais consomem agrotóxicos, e estão inseridas no contexto da mundialização do agronegócio cafeeiro, englobando desde o pequeno produtor até as multinacionais.

Há projetos de lei que avaliam riscos ditos "aceitáveis" para o uso e até mesmo consumo de agrotóxicos, alegando que em determinadas condições, o uso do veneno não aplicaria risco direto e imediato, no entanto, tal projeto não leva em consideração os diferentes grupos populacionais e etários expostos, sendo os grupos mais vulneráveis os compostos por crianças, gestantes e idosos, o que torna o "risco aceitável" irreal uma vez que não consideram as diversidades sociais e etárias muito menos os efeitos cinegéticos, que a combinação de diferentes venenos pode ocasionar quando associados o que claramente potencializa seu efeito danoso e prejudicial à saúde humana. Aliás, avaliar riscos como casos de câncer como aceitáveis é um tanto quanto desonesto.

A contaminação por agrotóxico se mostra tão alarmante e grave que hoje em dia há estudos como o de Palma (2011) que detectam a presença de agrotóxicos em amostras de leite materno afetando a camada social mais frágil e a que deveria ter uma proteção especial por parte do Estado, nossos bebês.

Outra contribuição que o trabalho de Bombardi contém refere-se aos indicadores de influência sobre a saúde do uso dos agrotóxicos. Bombardi ressaltou que "no período (...) foram notificadas 25.350 tentativas de suicídio através do uso de agrotóxicos, isto significa uma média de 2.300 tentativas de suicídio por ano, ou seja, uma média de seis tentativas de suicídio por dia, com a utilização de agrotóxicos". (BOMBARDI, 2012, p. 10).

Decorrente do fato exposto acima, Bombardi esclareceu que:

Neste período, no país, ocorreram 1876 casos de morte por intoxicação com agrotóxicos registrados pelo SINITOX. Isto significa que foram cerca de 170 mortes por ano (...) nos três estados da região Sul, a tentativa de suicídio responde por mais de $75 \%$ das mortes. Na região Sudeste, com exceção do Rio de Janeiro, o mesmo acontece, chegando a índices superiores a $80 \%$ em 
Minas Gerais e Espírito Santo. Com relação à região Nordeste, em alguns estados como é o caso de Pernambuco e Ceará, a tentativa de suicídio alcança quase $100 \%$ dos casos de morte notificados. (BOMBARDI, 2011, p. 13).

As culturas que mais utilizam agrotóxicos no país são justamente aquelas produzidas no modelo do agronegócio, cultivadas em grandes áreas de monocultivo e voltadas para a exportação, como é o caso da soja, que é responsável por $51 \%$ do volume total de agrotóxicos comercializados no país.

Além de controlar a fabricação dos agrotóxicos, essas empresas também controlam a produção e comercialização de sementes, gerando um ciclo vicioso de consumo. Desse modo, o agricultor que passa a utilizar essas sementes transgênicas e venenos, será sempre dependente dessas empresas.

\section{Guaranésia e o contexto Sulmineiro}

A área de estudo retratada é o município de Guaranésia- MG (Figura 1) que se localiza no sul do estado de Minas Gerais estando inserido na Região Geográfica Imediata de Guaxupé no sul de Minas Gerais. Em sua extensão territorial de 294 km², além da sede municipal, temos um distrito, Santa Cruz da Prata, e mais oito comunidades composta por bairros rurais, o distrito de Santa Cruz da Prata situa-se a 16 $\mathrm{km}$ de distância da sede municipal.

A atividade econômica que mais se destaca no município é a agricultura com cultivos que se baseiam na produção do café, da cana-de-açúcar, milho, arroz, feijão e laranja sendo que o café e a cana-de-açúcar são os produtos de maior peso no agronegócio do município, no entanto, nos últimos anos a atividade industrial do município demonstra franca expansão sendo o setor mais notável a indústria têxtil, que vai de prestação de serviços, como bordados e estampagem às grandes indústrias de fiação. $\mathrm{O}$ comércio local na última década se desenvolveu aceleradamente com o crescimento de bairros geograficamente mais altos que a região central, concentrando-se em uma rua conhecida como a "rua do comércio", onde é possível encontrar praças de alimentações, restaurantes, confecções e é neste recorte espacial que está localizada a feira livre, importante centro de comercialização de produtos do campo. Escolhemos o município de Guaranésia- MG por acreditar que este seja uma amostra da realidade sul mineira, já que dispõem de uma organização social, política e econômica semelhante com os demais municípios que integram essa região. 
Figura 1: Mapa de localização da Região geográfica Imediata de Guaxupé e munícipio de Guaranésia - MG.



Fonte: IBGE. 2018

Segundo dados do Censo Agropecuário de 2017, 76,9\% do total dos estabelecimentos agropecuários brasileiros pertencem a grupos familiares. De acordo com o estudo a agricultura familiar constitui a base econômica de $90 \%$ dos municípios brasileiros com até 20 mil habitantes, caso que se relaciona ao município de Guaranésia que acompanha a média nacional.

A população de Guaranésia em 2010 era de 18.714 pessoas, destas 1.876 pessoas viviam no campo sendo cerca de 250 consideradas nos atributos da lei agricultores familiares, que cultivam principalmente café, soja, milho, cana de açúcar, legumes, frutas e verduras. Através de análises dos dados obtidos junto a Empresa de Assistência Técnica e Extensão Rural do Estado de Minas Gerais (EMATER-MG), dos 250 agricultores familiares do município apenas 10 agricultores cultivam suas produções sem o uso de agrotóxicos, ou seja, 96\% dos agricultores familiares do município em questão utilizam agrotóxicos comprados principalmente na COOXUPÉ (maior 
cooperativa de café do mundo localizada no município de Guaxupé-MG) e em lojas de implementos e insumos agrícolas.

É fundamental destacar a intensa participação das cooperativas no espaço sul mineiro, na região encontra-se a Cooxupé que é a maior e mais poderosa cooperativa de café do mundo. Atualmente, a cooperativa "possui mais de 14 mil cooperados - 95\% deles pequenos produtores que vivem da agricultura familiar," a cooperativa recebe grãos de 200 municípios no sul de Minas, Cerrado Mineiro e Vale do Rio Pardo (no estado de São Paulo). (COOXUPÉ, 2019).

Em relação às características referentes aos estabelecimentos familiares e pessoal ocupado na agricultura municipal, percebemos uma grande maioria de agricultores familiares, que produzem atrelando sua venda ao mercado interno e externo, sendo dependentes de assistências técnicas promovidas pela Cooxupé, e dependendo de incentivos creditícios para a compra de implementos agrícolas e agrotóxicos.

As funções da cooperativa são diversificadas perpassando pelo apoio técnicofinanceiro, armazenagem, exportação, beneficiamento e industrialização do café. A influência da Cooxupé, no sul de minas, faz com que ela rivalize com as outras cooperativas na região.

A cooperativa já é também uma das maiores empresas do Brasil. A força da Cooxupé pode ser medida pelo seu grande número de cooperados, número superior ao de muitas corporações. Mas a amplitude da cooperativa é tamanha que ela faz parte do conselho da Bovespa há mais de 15 anos e opera na Bolsa Inter Continental Exchange's (ICE), em Nova Iorque, além de outros mercados internacionais de commodities.

Mesmo com a influência da cooperativa na adoção de agroquímicos para produção encontramos 10 agricultores no município de Guaranésia- MG que não utilizam de agrotóxicos em suas produções. A não utilização de agrotóxicos está relacionada a participação desses agricultores ao Programa Nacional de Alimentação Escolar (PNAE), programa destinado ao fornecimento de alimentos às escolas do município, assim como abastecem a feira livre da agricultura familiar, suas principais produções contam com legumes, verduras e frutas. A feira livre da agricultura familiar, que têm sido ao longo dos anos fomentada e fortalecida pela Emater em conjunto com a Prefeitura Municipal, conferindo então um importante canal de comercialização. De 
acordo com os dados obtidos junto a EMATER-MG o fornecimento destes alimentos as escolas geraram uma renda de aproximadamente $\mathrm{R} \$ 129.723,00 \mathrm{em} 2018$. Cabe salientar que a não utilização de agrotóxicos é condição básica dentre os requisitos para ser contemplado por esse programa governamental.

A feira livre da agricultura familiar no município de Guaranésia-Mg é uma iniciativa da Prefeitura Municipal juntamente com a Secretaria de Meio Ambiente e Agropecuária e o Departamento de Tributos e faz parte do programa "Aqui Tem Feira", onde alguns agricultores participantes de programas sociais (agricultura familiar, PNAE, etc.) foram contemplados com "Kits feira" contendo barracas ofertadas a eles, em regime de comodato. Este projeto conta ainda com o apoio da Emater-Mg, que auxilia na instrução de boas práticas no manejo de produtos agropecuários e como levar esse produto até $\mathrm{o}$ consumidor final.

Figura 2: Feira livre de Guaranésia-MG.

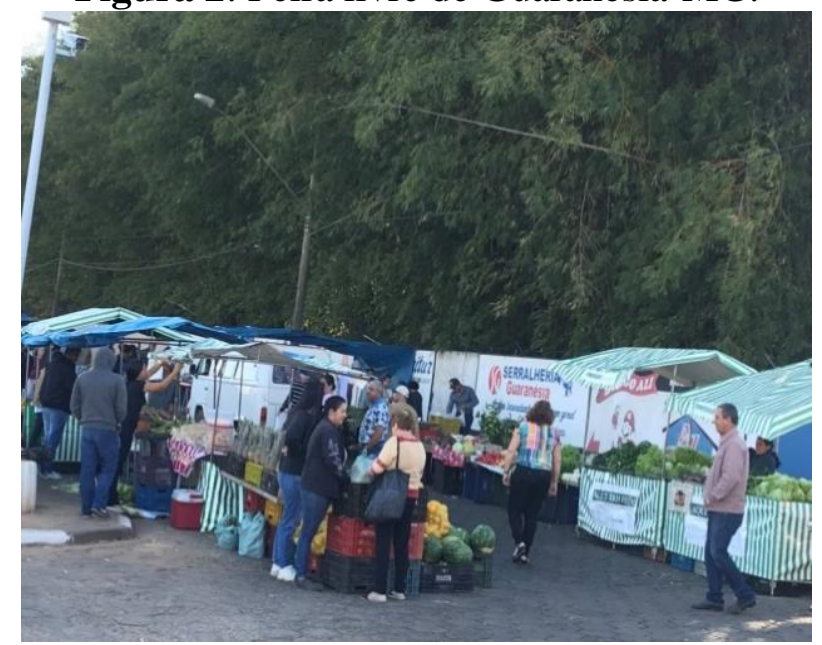

Fonte: Trabalho de campo, 2019.

Dos produtos oferecidos pela feira livre da agricultura familiar são ofertados principalmente verduras, frutas, legumes, quitutes, doces e artesanatos.

A feira livre da agricultura familiar é composta por agricultores familiares residentes no município de Guaranésia-MG, sendo essa condição (ser residente) determinante para ser contemplado com o programa. Os produtos são plantados em sítios e chácaras próprios ou arrendados localizados na área rural, distrito e bairros rurais do município. É de fundamental importância salientar que a partir dos dados obtidos $80 \%$ dos feirantes são residentes do município, sendo o restante de cidades vizinhas como Guaxupé - MG, Juruaia - MG e São Jose do Rio Pardo - SP, portanto não 
são contemplados com os benefícios do programa 'feira da agricultura familiar' havendo a necessidade de pagamento de um alvará no valor de duzentos e onze reais ao ano para regularizarem a exposição de seus produtos na feira.

$O$ funcionamento da feira acontece ao menos duas vezes por semana preferencialmente aos domingos e na quinta feira, dias em que população local e da região podem adquirir na feira produtos alimentícios (frutas, verduras, legumes, doces, biscoitos, bolos) além de artesanato (caixas decorativas, bordados, trabalhos com barbantes, linhas e com tecido) (Figura 3).

Figura 3: Barraca oferecida pela EMATER-MG.

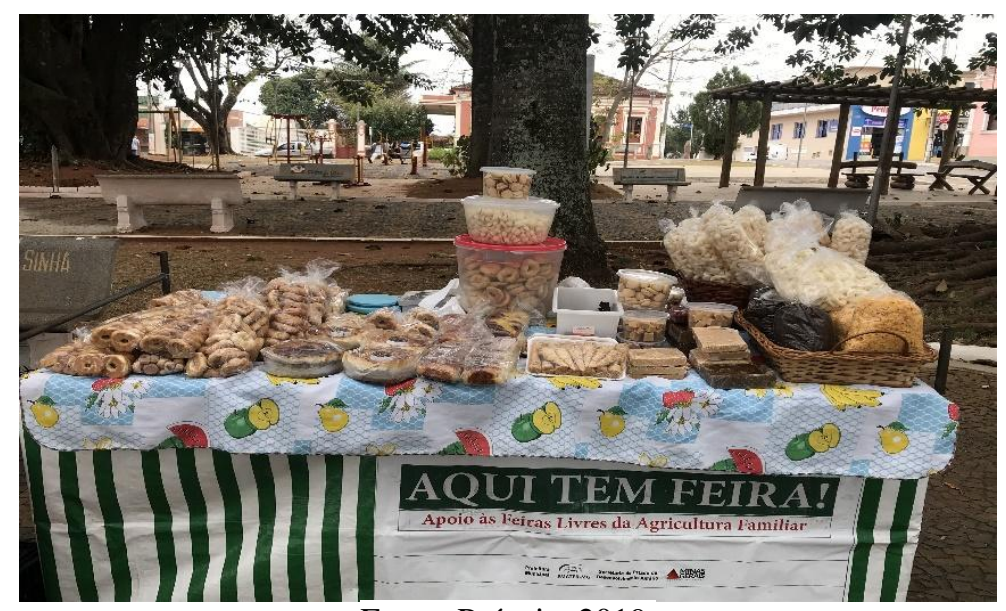

Fonte: Própria, 2019.

Em cada barraca há um tipo de produto específico à venda, sendo que a maioria desses produtos oferecidos ao consumidor pelo próprio produtor. Esse tipo de comércio é típico de uma economia espacial diversificada e com seus atributos específicos. Os produtos oferecidos pelos agricultores familiares contemplados pelo programa municipal são orgânicos, portanto, livre de agrotóxicos.

Em entrevista com os representantes do Governo Municipal, os mesmos afirmam esta é uma ação muito positiva, pois dá o primeiro passo na valorização dos pequenos agricultores, provocando neles o espírito cooperativista e também fomentando a agregação de valor aos produtos comercializados

\section{Cafeicultura em Guaranésia e no contexto regional}

Como já mencionado, a presença da produção de café é marcante na economia da região, sendo o principal produto do agronegócio e da mundialização da agricultura. 
Com a presença da maior cooperativa de café do mundo na região a produção cafeeira se torna ainda mais expressiva. Em relação a produção de café arábica, a Cooxupé é responsável por 14,48\% da produção nacional e 20,64\% do estado de Minas Gerais, considerando os dados de 2016. No item exportação, a Cooxupé enviou cerca de quatro milhões de sacas, para 49 países, no ano passado. O que podemos evidenciar que sua importância ultrapassa os limites regionais e nacionais e passa a exercer uma importância global.

A Região Geográfica de Guaxupé, foi se tornando uma das principais regiões produtoras no Brasil e o crescimento da produção é gradativa (Tabela 1) e em 30 anos aumentou quase $600 \%$ a quantidade produzida na região.

Tabela 1 - Quantidade produzida de café, em toneladas, na Região Geográfica Imediata de Guaxupé, nos anos de 1986, 1996, 2006 e 2016.

\begin{tabular}{ccccc}
\hline Município & $\mathbf{1 9 8 6}$ & $\mathbf{1 9 9 6}$ & $\mathbf{2 0 0 6}$ & $\mathbf{2 0 1 6}$ \\
\hline Arceburgo & 550 & 2786 & 2160 & 2205 \\
Cabo Verde & 4195 & 9041 & 17640 & 12458 \\
Guaranésia & $\mathbf{1 1 1 8}$ & $\mathbf{5 7 1 0}$ & $\mathbf{5 9 6 6}$ & $\mathbf{8 3 6 3}$ \\
Guaxupé & 1502 & 7019 & 8928 & 9072 \\
Juruaia & 440 & 2562 & 5161 & 9180 \\
Monte Belo & 1888 & 6426 & 4320 & 7031 \\
Muzambinho & 2622 & 7504 & 8580 & 12177 \\
Nova Resende & 2098 & 9352 & 16128 & 20800 \\
São Pedro da União & 533 & 3195 & 5148 & 6624 \\
\hline \multicolumn{5}{c}{ Total } \\
\hline Fonte: Censos Agropecuários (IBGE, 1985, 1995/96, 2006, 2017).
\end{tabular}

Conforme a tabela 1, observa-se que Guaranésia aumentou em 7,5 vezes a quantidade produzida de café em 30 anos, acima da média regional. Esse aumentou foi conseguido com incentivos estatais e sobretudo, pela atuação da COOXUPÉ, envolvendo pequenos, médios e grandes produtores do município.

De acordo com o relatório de gestão e comercialização financeiras da Cooxupé (2019), os pequenos agricultores familiares totalizam 10.935 produtores e são responsáveis por $97,6 \%$ do total de produção das sacas de café destinadas a essa cooperativa anualmente.

O café é o produto agrícola de maior representatividade sendo do total de estabelecimentos 293 produtores de café, correspondendo a 3.180 hectares de áreas plantada o que produziu 8.363 toneladas em 2016 (Figura 4). A cana de açúcar outro 
produto do agronegócio local é produzido em 18 estabelecimentos ocupando uma área equivalente a 1.123 hectares que produziram 85.785 toneladas em 2018.

Figura 4 - Mapa da Produção de Café na Região Geográfica Imediata de Guaxupé, 2016.

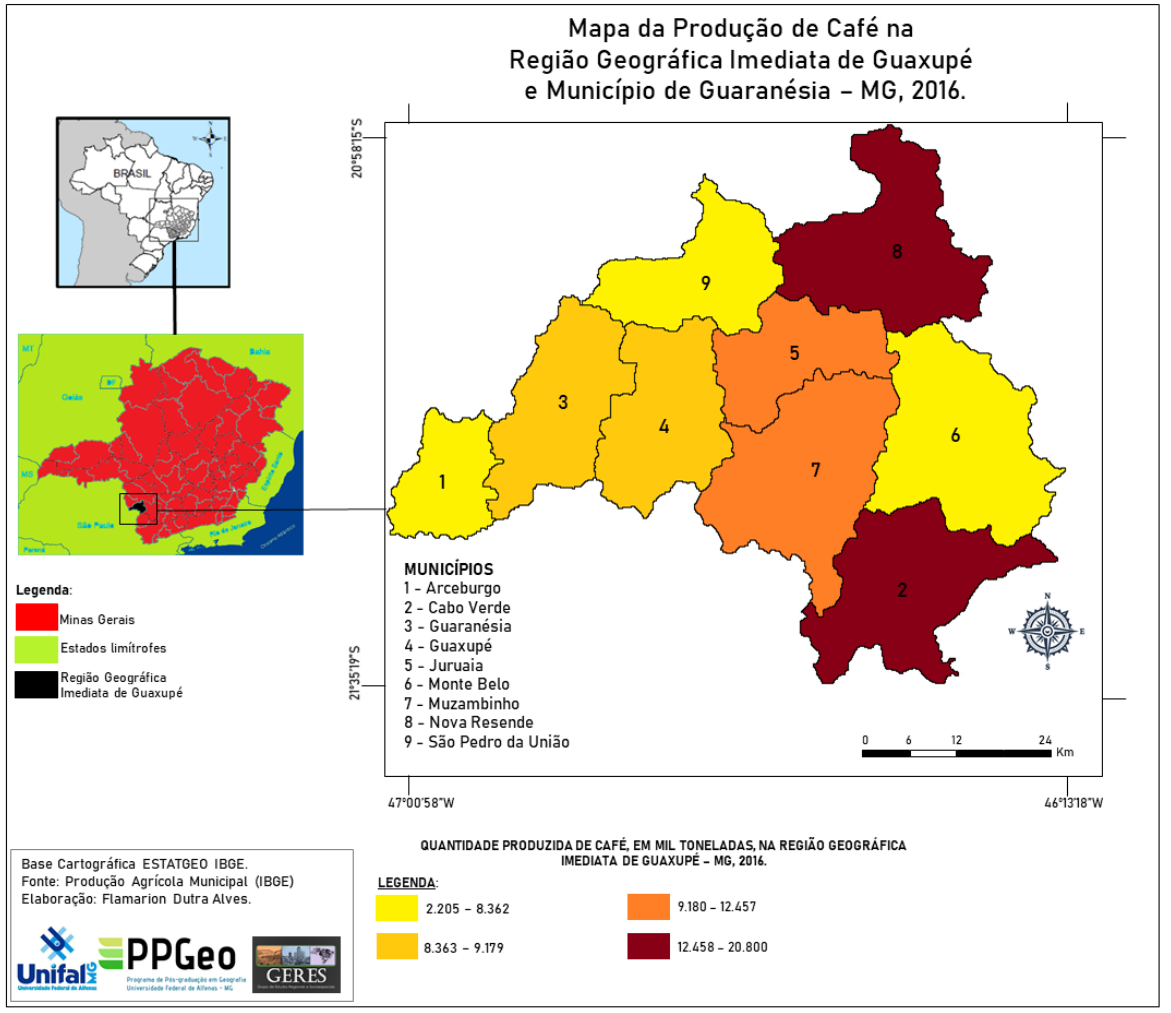

Fonte: IBGE (2017).

Os municípios de Cabo Verde e Nova Resende são os que mais produzem café na região, 20.800 e 12458 toneladas de café respectivamente, enquanto Guaranésia produz 8.363 toneladas de café, sendo mesmo assim, valores expressivos e que inserem o município na dinâmica do agronegócio do café.

Quanto a territorialização do café nos municípios da Região Geográfica de Guaxupé, essa cultura agrícola ocupa 46.595 hectares, dos 83.041 hectares destinado a agropecuária, ou seja, $56 \%$ do espaço agrário é dominado pela cafeicultura (Figura 5).

A ocupação territorial do café no espaço agrária, demostra como o agronegócio cafeeiro atinge todos estratos de produtores rurais. Com forte presença da agricultura familiar na região, o café está territorializado em 10.000 hectares no município de Cabo Verde, e em 3.180 hectares em Guaranésia. 
Figura 5 - Mapa da Área plantada de Café na Região Geográfica Imediata de Guaxupé, 2016.

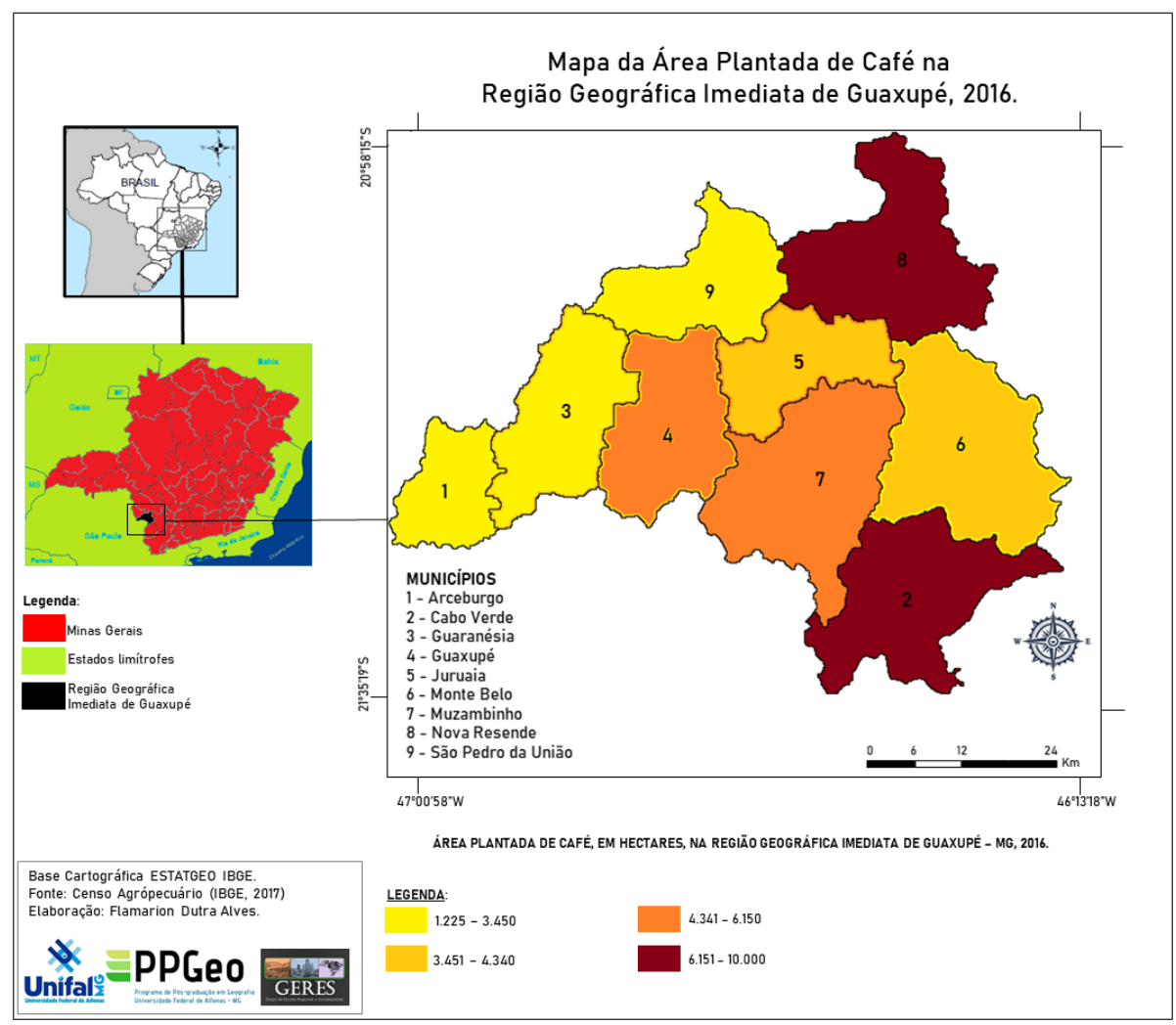

Fonte: IBGE (2017).

Um fator preocupante em relação às características destes agricultores está na baixa escolaridade que quando atrelada ao uso de agrotóxicos podem ter consequências catastróficas a saúde dos mesmos.

As vendas dos venenos utilizados na agricultura do município se efetuam por meio da Cooxupé que trabalha como um grande atravessador intermediando as relações cafeicultor/mercado consumidor. Além disso, a cooperativa presta assistência técnica, são também distribuidoras de insumos para agricultura, abrangendo uma linha bem diversificada de produtos, que compreende de máquinas agrícolas a adubos e defensivos agrícolas.

De acordo com o manual de boas práticas agrícolas da própria Cooxupé nota-se que alguns agrotóxicos comercializados na região são extremamente tóxicos, como Counter 150g, Granutox 150g, Baron/ Baysiston GR, Temik 150, e outros são altamente tóxicos, Deltaphos, Hostathion 400 Br, Fury 180 Ew/ Fury 400, Ec/Mustang 350 , Apache 100 Gr/Rugby 100 Gr/Rugby 200 Cs, Diafuran 50/Furacarb 100 Gr/ Furadan ,e Nemacur. 
Esses venenos são utilizados via foliar, onde o produto é diluído em água e aplicado sobre as folhas das plantas, ou via solo, onde podem ser empregados granulados ou diluídos e aplicados diretamente no solo. Nas unidades avançadas da Cooxupé, o produtor tem acesso a uma infinidade de agrotóxicos, recomendados pela sua assistência técnica.

Destacamos aqui que o papel exercido pelas cooperativas é decisivo para a ampliação do consumo de agrotóxico por agricultores familiares na região, onde ela exerce a função de principal atravessadora na compra e vendas destes insumos agrícolas, tais fatos nos chamam atenção, devido a isso, faremos uma análise exploratória sobre esse fato em nossa pesquisa.

Com relação à presença de organizações de agricultores familiares encontramos ativas no município quatro associações: Associação dos Produtores familiares do bairro Matão e Mandaguari (ASPRO), Associação dos Produtores Familiares do bairro Cachoeira e Bugio (ASCAB), Associação dos Agricultores Familiares de Guaranésia (AAFAG) e Câmara da Mulher Empreendedora de Guaranésia (MG).

De acordo com o Censo agropecuário do IBGE de 2017 os estabelecimentos agropecuários ocupam uma área equivalente a 23.691 hectares. Em relação à utilização das terras tem-se 4.849 hectares de lavouras permanentes e 2.236 hectares de lavouras temporárias, contando também com áreas de florestas e matas fechadas, pastagens e sistemas agroflorestais.

São 563 estabelecimentos agropecuários sendo em sua maioria de posse de proprietários individuais, adultos, do sexo masculino e com ensino fundamental incompleto. A maioria (286 estabelecimentos) recebe assistência técnica, realiza a adubação frequente (409 estabelecimentos), obtiveram financiamento para custeio de sua produção (467 estabelecimentos) e utilizam agrotóxicos (363 estabelecimentos). No contexto sul mineiro, mais de 60 mil propriedades rurais utilizaram agrotóxicos em suas plantações (Figura 6).

Das 15 regiões geográficas imediatas que compõem o Sul de Minas Gerais, as que mais consomem agrotóxicos na produção agrícola, são aquelas que estão ligadas ao agronegócio do café. As regiões imediatas de Pouso Alegre, Alfenas e Guaxupé lideram o consumo de agrotóxico, com 11.597, 9.972 e 7.190 estabelecimentos rurais 
respectivamente. Guaranésia estando na Região Geográfica Imediata de Guaxupé, confirma a relação entre agrotóxico e a cafeicultura.

Figura 6 - Número de estabelecimentos rurais que utilizaram agrotóxico nas Regiões

Geográficas Imediatas do sul de Minas Gerais, 2017.

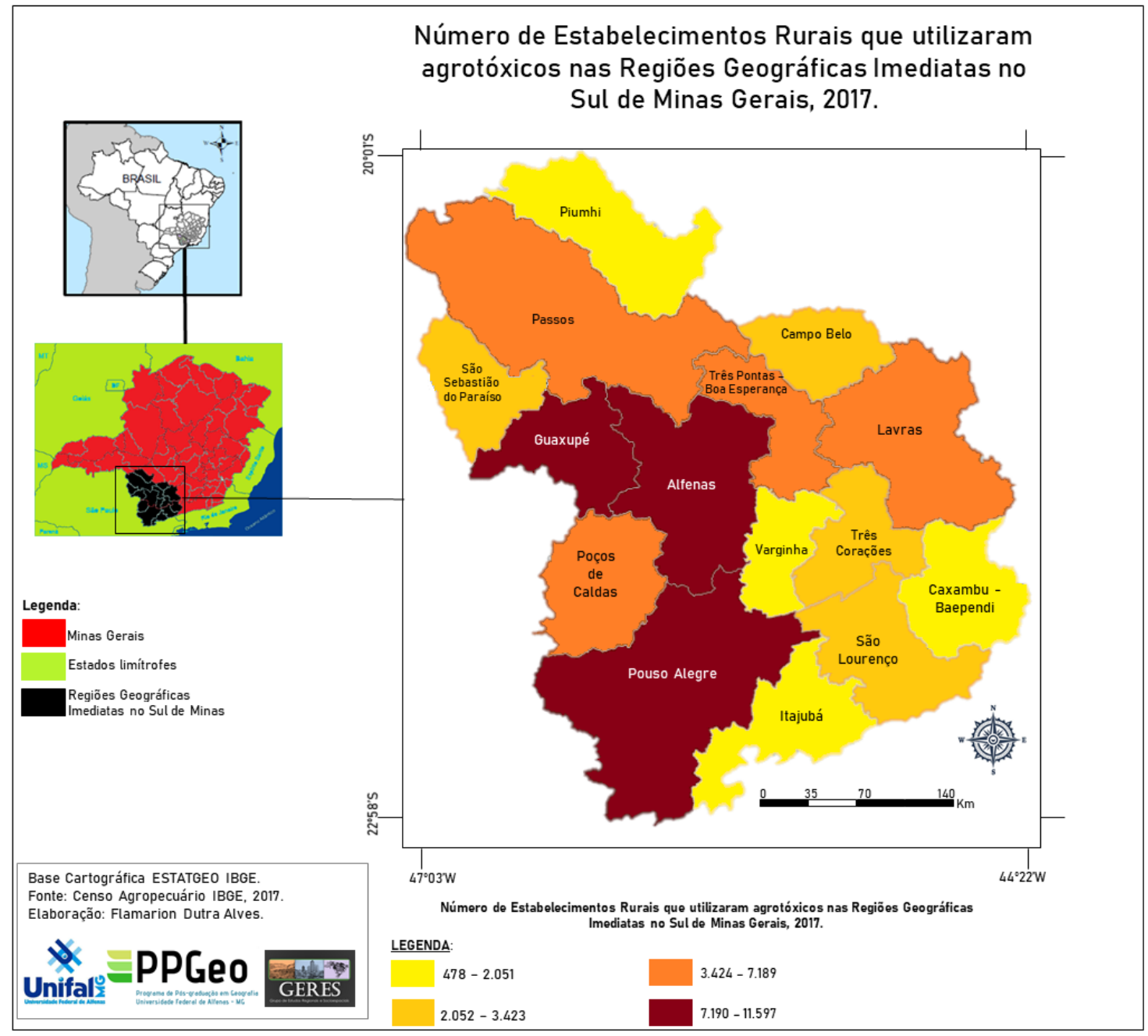

Fonte: IBGE (2017).

Conforme os dados do Censo Agropecuário de 2006, no sul de Minas Gerais foram notificados 285 casos de intoxicação por agrotóxico, mas 38.927 propriedades rurais fizeram uso do agrotóxico nas suas lavouras, demostrando territorialização na agricultura, tanto nas propriedades de caráter familiar como nas empresariais e multinacionais (ALVES, 2019a). 


\section{Considerações finais}

Observa-se a crescente utilização de agrotóxicos após as décadas de 1960 no Brasil e no mundo. $\mathrm{O}$ modelo adotado no Brasil incentiva sobremaneira o uso desse aparato químico na agricultura, e os efeitos a saúde e ao meio ambiente estão sendo revelados em pesquisas recentes.

A agricultura familiar ocupa um espaço importante nesse contexto, pois é o grupo social mais sensível a essas práticas danosas, tanto socioambiental quanto economicamente, devido ao tamanho das propriedades, a participação direta da família no manejo das lavouras e contato com os agrotóxicos e pela diversidade de alimentos produzidos, sobretudo, os que são ingeridos in natura.

No sul de Minas Gerais e em Guaranésia, a agricultura familiar está associada a produção de café e inserida na mundialização via cooperativas, e nesse sentido, a pressão econômica impõe aos agricultores familiares desafios para sua manutenção e reprodução de forma segura. É importante as ações do Estado, como o Programa de aquisição de alimentos para escolas e a assistência técnica de entidades como a EMATER para auxiliar na produção orgânica. Entretanto, a "força" e lobby do mercado e das cooperativas somados a atual inércia e retrocessos do Estado, nas esferas estadual e principalmente federal, nas políticas de valorização da agricultura familiar são obstáculos para a estruturação de uma política de alimentação saudável e segura para a população.

\section{REFERÊNCIAS}

ABRAMOVAY, R. Muito além da economia verde. São Paulo: Ed. Abril, 2012. AGÊNCIA PÚBLICA / REPÓRTER BRASIL / PUBLIC EYE - Sobre o mapa dos agrotóxicos na água. Disponível em: < https://apublica.org/2019/05/sobre-o-mapa-dosagrotoxicos-na-agua >. Acesso em: $20 \mathrm{dez} .2019$.

ALVES, F.D. Agronegócio do café no sul de Minas Gerais: territorialização, mundialização e contradições. In: SIMPÓSIO INTERNACIONAL DE GEOGRAFIA AGRÁRIA. IX. ,2019. Recife. Anais [...]Recife: UFPE, 2019a. p.1-18.

ALVES, F.D. O agronegócio do café e a territorialização no Sul de Minas Gerais. In: ALVES, Flamarion Dutra et al. (org.). A dimensão política no espaço: conflitos e desigualdades territoriais na sociedade contemporânea. Alfenas: Editora UNIFAL-MG, 2019b. p. 306-323.

AGÊNCIA NACIONAL DE VIGILÂNCIA SANITÁRIA - ANVISA. Ministério da Saúde. Resolução da Diretoria Colegiada - RDC No 296, DE 29 DE JULHO DE 2019. 
Disponível em: <

http://portal.anvisa.gov.br/documents/10181/2858730/RDC_296_2019_.pdf/ca693bd5e688-48e0-b072-0ece1dfca268>. Acesso em: 30 maio 2020.

BOMBARDI, L.M. Geografia do uso de agrotóxicos no Brasil e conexões com a União Europeia. São Paulo: FFLCH - USP, 2017.

BOMBARDI, L.M. Agrotóxicos e agronegócio: arcaico e moderno se fundem no campo brasileiro. Direitos Humanos no Brasil 2012. Relatório da Rede Social de Justiça e Direitos Humanos. São Paulo, 2012.

BOMBARDI, L.M. Intoxicação e morte por agrotóxicos no Brasil: a nova versão do capitalismo oligopolizado. São Paulo: Boletim DATALUTA. Set. 2011.

BRUM, A.J. Modernização da agricultura: trigo e soja. Petrópolis: Vozes, 1988.

CARNEIRO, F.F. et al. (org.) Dossiê ABRASCO: um alerta sobre os impactos dos agrotóxicos na saúde. Rio de Janeiro: EPSJV; São Paulo: Expressão Popular, 2015.

DELGADO, G. C. Capital financeiro e agricultura no Brasil 1965-1985. Campinas: Ícone Editora/Editora Unicamp, 1985.

ELIAS, D. Globalização e agricultura. São Paulo: EDUSP, 2003.

GRAZIANO DA SILVA, J. A nova dinâmica da agricultura brasileira. 2. ed. São Paulo: UNICAMP, 1998.

GRAZIANO DA SILVA, J. Do complexo rural aos complexos agroindustriais. In: A nova dinâmica da agricultura brasileira. Campinas: UNICAMP /IE, 1996.

GRAZIANO, NETO, F. Questão agrária e ecologia: crítica da moderna agricultura. 2. ed. Brasiliense: São Paulo, 1985.

GUILHON, B. "Technologie, Organisation et Performances: le cas de la FirmeReseau". Revue d'Economie Politique, p. 46-60, 1992.

Instituto Brasileiro de Geografia e Estatística - IBGE. Censo Agropecuário 2017. Disponível em: <https://sidra.ibge.gov.br/pesquisa/censo-agropecuario/censoagropecuario-2017>. Acesso em: 30/05/2020.

KAGEYAMA, A. et al. (org.). O novo padrão agrícola brasileiro: do complexo rural aos CAIs. In: DELGADO, G. C.; GASQUES, José G.; VILLA VERDE, C. M. (org.) (org.). Agricultura e políticas públicas. IPEA, 1990. p. 113-223.

MAZZALI, L. O processo recente de reorganização agroindustrial: do complexo à organização em rede. São Paulo: UNESP, 2000. 170p. 
MINISTÉRIO DA SAÚDE. Agrotóxicos na ótica do Sistema Único de Saúde.

Secretaria de Vigilância em Saúde, Departamento de Vigilância em Saúde Ambiental e Saúde do Trabalhador. - Brasília: Ministério da Saúde, 2018.

MÜLLER, G. Complexo agroindustrial e modernização agrária. São Paulo: Ed. HUCITEC: EDUC, 1989.

OLIVEIRA, A.U. A agricultura camponesa no Brasil. 4. ed. São Paulo: Contexto, 2002.

OLIVEIRA, A.U. A mundialização da agricultura brasileira. São Paulo: Iandé Editorial, 2016.

OLIVEIRA, A.U. Modo capitalista de produção e agricultura. São Paulo: Ática, 1986.

PALMA, D.C.A. Agrotóxicos em leite humano de mães residentes em Lucas do Rio Verde - MT. 2011. Dissertação (Mestrado em Saúde Coletiva) - Faculdade de Saúde Coletiva da Universidade Federal de Mato Grosso, Cuiabá, 2011.

PELAEZ, V.; MELO, M.; HOFMANN, R.; HAMERSCHMIDT, P.; MEDEIROS, G.; MATSUSHITA, A.; TEODOROVICZ, T.; MOREIRA, F.; WELINSKI, J.; HERMIDA, C. Monitoramento do mercado de agrotóxicos. Departamento de Economia, UFPR, 2010 .

PELAEX, V.; TERRA, F.H.B; SILVA, L.R. A regulamentação dos agrotóxicos no Brasil: entre o poder de mercado e a defesa da saúde e do meio ambiente. Revista de Economia, Curitiba, v. 36, n. 1, 2010. p. 27-48.

SANTOS, M.; SILVEIRA, M. L. (2001) O Brasil: território e sociedade no início do século XXI. 13. ed. São Paulo: Record, 2010.

SIQUEIRA, S. L. de; KRUSE, M. H. L. Agrotóxicos e saúde humana: contribuição dos profissionais do campo da saúde. Revista da Escola de Enfermagem da USP, v.42, n.3, p. 584-590, 2008.

SISAGUA. Sistema de Informação de Vigilância da Qualidade da Água para Consumo Humano. Ministério da Saúde. Disponível em:

<http://sisagua.saude.gov.br/sisagua/paginaExterna.jsf >. Acesso em: 30 maio 2020.

SNA - Sociedade Nacional de Agricultura. Agrotóxicos registrados têm pouca inovação. Disponível em: < https://www.sna.agr.br/agrotoxicos-registrados-tem-poucainovacao>. Acesso em: 30 maio 2020.

ZHANG L, et al. Exposure to glyphosate-based herbicides and risk for Non-Hodgkin Lymphoma: A meta-analysis and supporting evidence. Mutation Research/Reviews in Mutation Researc, Amsterdam, v.781, 2019, p.186-206.

Recebido em 30/12/2019.

Aceito para publicação em 08/04/2020. 